\title{
STRAIN DIFFERENCES IN ASPIRIN-INDUCED GASTRIC ULCERATION IN RATS
}

\author{
Tetsuro URUSHIDANI, Susumu OKABE*, Koji TAKEUCHI \\ and Keijiro TAKAGI \\ Deparment of Chemical Pharmacology, Faculty of Pharmacentical Sciences, \\ University of Tokyo, Bunkyo-ku, Tokyo 113, Japan
}

Accepted February 8, 1978

\begin{abstract}
We found that there are strain differences in aspirin-induced ulceration in pylorus-ligated rats; the ulcer indices varied, from high to low, in the following order: Donryu - Sprague-Dawley. Wistar. Several experiments including analysis of gastric contents or ionic flux, determination of serum aspirin esterase activity, absorption of aspirin from the stomach, prothrombin time and hexosamine content in gastric mucosa and juice were performed to elucidate the origin of the differences. A significantly higher acid output in Donryu rats, and higher hexosamine content in the gastric mucosa of Wistar rats were noted. However, it appears unlikely that these factors only contribute to the marked strain difference in aspirin-induced ulcers. The possible different sensitivity of gastric mucosal cell itself to aspirin must be considered.
\end{abstract}

Aspirin induced gastric mucosal ulcers in several strains of rats, including SpragueDawley $(1-3)$, Wistar $(4,5)$ or Donryu $(6,7)$ derived from the Wistar strain and which are used for laboratory experiments in Japan. We report herein different severity indices of aspirin ulcers in rats of three strains, and several factors which might contribute to the differences are discussed. To date there has apparently been no documentation concerning strain differences in aspirin-induced ulcers in rats.

\section{MATERIALS AND METHODS}

Male Donryu (Nihon Rat Co.), Sprague-Dawley (Clea Japan Inc.), and Wistar (Nihon Rat Co.) strain rats, weighing 180-200 g, were used. In all experiments described below, the animals were deprived of food but allowed free access to water for $24 \mathrm{hr}$ before each procedure.

\section{Induction of aspirin ulcers}

Aspirin ulcers were produced by the standard method of Okabe et al. (6). Briefly, the pylorus of each strain of rat was ligated under ether anesthesia. Ten min later, aspirin $100 \mathrm{mg} / \mathrm{kg}$ suspended in $1 \%$ carboxymethylcellulose (CMC) solution was given orally in a volume of $0.5 \mathrm{ml} / 100 \mathrm{~g}$ of body wejght. Seven hr after the aspirin administration, the animals were sacrificed and the stomach of each was removed and gastric contents were collected. Subsequently, the stomach was inflated by injection of $12 \mathrm{ml}$ of $1 \%$ formalin and immersed in $1 \%$ formalin for $10 \mathrm{~min}$. The stomach was then incised along the greater curvature and examined for the presence of gastric ulcers in the glandular portion. The length of each lesion $(\mathrm{mm})$ was measured under the dissecting microscope $(10 \times)$, summed

* Present address: Department of Applied Pharmacology, Kyoto College of Pharmacy, Yamashina, Kyoto 607. 
and used as an ulcer index. The observer who measured the ulcers was unaware of which strain of rats had been tested. The gastric contents collected were centrifuged and analyzed for volume and acidity; the acidity was determined by titration of the gastric juice with $0.1 \mathrm{~N} \mathrm{NaOH}$ to $\mathrm{pH} 7.0$ by using the Autoburette (Radiometer). Acid output was expressed as $/ \mathrm{Eq} / \mathrm{hr}$. The concentrations of $\mathrm{Na}^{+}$and $\mathrm{K}^{+}$ions were measured on a Hitachi flamephotometer; $\mathrm{Na}^{+}$and $\mathrm{K}^{+}$outputs were expressed as , $\mathrm{Eq} / \mathrm{hr}$. Pepsin activity was determined by Anson's method (8); pepsin output was expressed as mg tyrosine per hr. Ten samples of gastric juice were selected randomly for gastric content analysis. Control animals were given the same volume of $1 \% \mathrm{CMC}$ solution alone.

\section{Ionic flux through the gastric mucosa}

Under ether anesthesia, the pylorus and cardia of each rat stomach were ligated and a subdiaphragmatic bilateral vagotomy was performed. A polyethylene tube was inserted into the forestomach through a small incision and secured with a ligature. After the abdomen was closed and the animals had recovered from anesthesia, the stomach was washed with saline. Eight $\mathrm{ml}$ of test solution $(100 \mathrm{mM} \mathrm{HCl}$ and $54 \mathrm{mM} \mathrm{NaCl}$ ), containing $40 \mathrm{mg} /$ liter phenol red as a volume indicator, were instilled into the stomach through the fistula by a syringe. After gentle stirring, $2 \mathrm{ml}$ of the solution were immediately sampled $\left(\mathrm{I}_{1}\right)$ and the end of the fistula was closed. One hr later, the residual solution was collected $\left(F_{1}\right)$. One $\mathrm{ml}$ of aspirin suspension ( $100 \mathrm{mg} / \mathrm{kg}$ in CMC solution) was then injected together with $5 \mathrm{ml}$ of test solution. As a control, CMC solution was used instead of aspirin. Thirty min later, the stomach was cmptied and washed several times with saline, and again $8 \mathrm{ml}$ of test solution was instilled and $2 \mathrm{ml}$ was sampled $\left(\mathbf{I}_{2}\right)$. One hr after the latter procedure, the residual solution was collected $\left(F_{2}\right)$. Each sample of $I_{1}, F_{1}, I_{2}$ and $F_{22}$ was analyzed for volume, concentration of phenol red, $\mathrm{H}^{+}, \mathrm{Na}^{+}, \mathrm{K}^{+}$and $\mathrm{Cl}^{-}$. The concentration of phenol red was determined by the method of Hunt and Knox (9). Chloride concentration was determined by use of a chloride meter (Radiometer). The ion net flux $\left(\mathrm{X}_{1}\right)$ before the treatment of aspirin (or $\mathrm{CMC}$ solution alone) was calculated as follows: $\mathrm{X}_{1}=\mathrm{V}_{\mathrm{F} 1}[\mathrm{X}]_{1: 1}-\mathrm{V}_{\mathrm{II}}[\mathrm{X}]_{\mathrm{I} 1}$ where $V_{F 1}$ and $V_{I t}$ are calculated from the measured volume and phenol red concentration, and $[X]$ is the concentration of each ion. The net flux after the drug treatment $\left(X_{2}\right)$ was calculated the same way, and the change in mucosal permeability of an ion caused by aspirin (or CMC solution alone) was cxpressed as follows: $\mathrm{X}=\mathrm{X}_{2}-\mathrm{X}_{1}$.

\section{Determination of aspirin acyl-hydrolase (aspirin esterase) activity}

Determination of aspirin esterase activity was carried out according to the modificd method of Menguy et al. (10). Blood was withdrawn from each rat via the vena cava and centrifuged for $30 \mathrm{~min}\left(4^{\circ} \mathrm{C}, 4,000 \mathrm{rpm}\right)$. One $\mathrm{ml}$ of serum was mixed with $0.4 \mathrm{ml}$ of $15 \mathrm{mM}$ aspirin and $1.6 \mathrm{ml}$ of $0.06 \mathrm{M}$ Tris buffer ( $\mathrm{pH} \mathrm{7.0)}$ ), and incubated for $1 \mathrm{hr}$ at $37^{\circ} \mathrm{C}$. The reaction was then stopped by adding $0.3 \mathrm{ml}$ of $6 \mathrm{~N} \mathrm{HCl}$. The reaction mixture was shaken with $30 \mathrm{ml}$ of ethylenedichloride for $5 \mathrm{~min}$ and centrifuged. Twenty $\mathrm{ml}$ of the organic phase was shaken with $10 \mathrm{ml}$ of distilled water containing $0.25 \mathrm{ml}$ of iron reagent (ferric nitrate $8.35 \mathrm{~g}$ in $500 \mathrm{ml}$ of water) for $5 \mathrm{~min}$. The optical density of the aqueous phase was measured 
using a spectrophotometer (Hitachi) at $520 \mathrm{~nm}$. Blanks were run through the procedure using Tris buffer instead of serum. Each sample was assayed in duplicate and the enzyme activity was expressed as $/ \mathrm{g}$ salicylic acid/ml of serum/hr.

\section{Measurement of salicylic acid and aspirin concentrations in blood}

Six of the pylorus ligated rats were subjected to the determination of aspirin and salicylic acid concentrations $5,15,30,60,180$ or $420 \mathrm{~min}$ after aspirin administration. Blood samples were collected from each rat and divided into 2 specimens of $3 \mathrm{ml}$ each. One specimen was subjected to the measurement for total salicylic acid in blood and the other for aspirin. Immediately after the sampling, the blood of aspirin treated rats was shaken with $0.5 \mathrm{ml}$ of $6 \mathrm{~N} \mathrm{HCl}$ and heated at $100^{\circ} \mathrm{C}$ for $10 \mathrm{~min}$ (11). After hydrolysis, the total amount of salicylic acid in blood was extracted with ethylenedichloride and determined in the manner described above. A standard curve was obtained from the same procedure using blood of an intact rat containing a known amount of salicylic acid. Aspirin in blood was extracted directly by the method of Cotty and Ederma (12). Immediatcly after the sampling, the blood was mixed with $0.5 \mathrm{ml}$ of $6 \mathrm{~N} \mathrm{HCl}$ and shaken with $30 \mathrm{ml}$ of ethylene dichloride for 5 min. After removing the blood layer by filtration, the organic phase was transferred to another tube. Then $0.1 \mathrm{ml}$ of $40 \%$ ceric ammonium nitrate and $5.9 \mathrm{ml}$ of water were added and the mixture was shaken for $1 \mathrm{hr}$. The aqueous layer was discarded and $20 \mathrm{ml}$ of the organic phase was shaken with $4 \mathrm{ml}$ of $1 \% \mathrm{NaHCO}_{3}$ for $10 \mathrm{~min}$. Two $\mathrm{ml}$ of the aqueous layer was heated at $100^{\circ} \mathrm{C}$ for $1 \mathrm{hr}$. The concentration of salicylic acid was measured by spectrophotofluorometry in $10 \mathrm{~N} \mathrm{NaOH} \mathrm{(Ex.} 295 \mathrm{~nm}$; Em. $405 \mathrm{~nm}$ uncorrected).

\section{Prothrombin time}

Quick's one stage prothrombin time test was performed in $12.5 \%$ serum using Bactothromboplastin (Difco) (13). The blood samples were obtained from pylorus-ligated rats which had been given either $100 \mathrm{mg}$ aspirin $/ \mathrm{kg}$ or the CMC solution $7 \mathrm{hr}$ before the test. A $0.2 \mathrm{ml}$ solution of $0.1 \mathrm{M}$ sodium oxalate was added to $1.8 \mathrm{ml}$ of the blood sample, and the preparation centrifuged $(2,000 \mathrm{rpm}$, for $10 \mathrm{~min})$. Serum $(0.1 \mathrm{ml})$ was diluted by adding $0.7 \mathrm{ml}$ of saline, and the prothrombin time was determined in this preparation according to the standard methods. These tests were done in triplicate.

\section{Hexosamine content in gastric mucosa and juice}

Both gastric mucosa and juice were obtained from pylorus-ligated rats that had been given aspirin or the CMC solution $7 \mathrm{hr}$ before the sampling. After the gastric contents were collected, the rumen of each stomach was discarded and the glandular portion was placed in absolute ethanol, acetone and ether in this order. After drying in vacuum, the gastric mucosa was weighed. Hexosamine content in the tissue or in the gastric contents was measured by the method of Masamune and Yoshizawa (14). Briefly, the mucosa with $1 \mathrm{ml}$ of distilled water or $1 \mathrm{ml}$ of gastric juice was hydrolysed with $1 \mathrm{ml}$ of $8 \mathrm{~N} \mathrm{HCl}$ in a boiling water bath for $9 \mathrm{hr}$. After cooling, the hydrolysate was neutralized with $1.5 \mathrm{ml}$ of $4 \mathrm{~N} \mathrm{NaOH}$, with the aid of phenolphthalein, followed by immediate addition of $0.3 \mathrm{~N} \mathrm{HCl}$ until it became acidic to BTB. The hydrolysate was then made up to $10 \mathrm{ml}$ with water and 
filtered. Two $\mathrm{ml}$ of solution was heated in a boiling water bath for $20 \mathrm{~min}$ with $1 \mathrm{ml}$ of acetylacetone reagent ( $1 \mathrm{ml}$ of acetylacetone in $50 \mathrm{ml}$ of $0.7 \mathrm{~N} \mathrm{Na}_{2} \mathrm{CO}_{3}$ ). After cooling, the mixture was diluted with $6 \mathrm{ml}$ of absolute ethanol and heated in a water bath $\left(65-70^{\circ} \mathrm{C}\right)$ for $10 \mathrm{~min}$ with $1 \mathrm{ml}$ of Ehrlich reagent $(0.8 \mathrm{~g}$ of dimethylaminobenzaldehyde in a mixture of $30 \mathrm{ml}$ of conc. $\mathrm{HCl}$ and $30 \mathrm{ml}$ of absolute ethanol), and cooled in water prior to measurement at the wave length of $537 \mathrm{~nm}$. Hexosamine content in the tissue was expressed as $\mu \mathrm{g} / \mathrm{g}$ of dry mucosa weight, and in the gastric juice, the value was expressed as $\mu \mathrm{g} / \mathrm{ml}$.

All values obtained were statistically analyzed using Student's $t$-test.

\section{RESULTS}

Aspirin ulcers

Ulcer indices of each strain of rats are shown in Table 1. Donryu strain rats showed a significantly higher ulcer index as compared with Sprague-Dawley or Wistar rats. The ulcer index of Sprague-Dawlcy rats was significantly higher than that of Wistar rats.

\section{Gastric secretion}

Table 2 shows the results of analysis of the gastric juice in pylorus-ligated rats given aspirin or $1 \% \mathrm{CMC}$ solution. In the group of the animals given $1 \% \mathrm{CMC}$ solution alone, the volume of gastric juice and acid output in Donryu rats was significantly higher than in the other strains. In the aspirin treated animals a significant reduction in acid output was confirmed in every strain and such was almost to the same degree. While an increment of $\mathrm{Na}^{+}$output was observed in every strain, the degree of change was not equal. The pepsin output in Donryu rats was found to be significantly higher than of Wistar rats.

Ionic fluxes in gastric juice.

As shown in Table 3, aspirin caused a significant reduction of $\mathbf{H}^{+}$ion output and increment of $\mathrm{Na}^{+}$output. The degree of ion fluxes in rats used was almost the same in the three strains. The changes of $\mathrm{K}^{+}$and $\mathrm{Cl}^{-}$ions were small in all three strains of rats.

Aspirin esterase activity

Aspirin esterase activity in Donryu rats was significantly higher than that of SpragueDawley or Wistar rats (Table 4).

Tarl.t 1. Aspirin ulecrs in Donryu, Sprague-Dawley or Wistar strain rats

\begin{tabular}{cccc}
\hline Group No. & Strain & $\begin{array}{c}\text { No. of } \\
\text { rats }\end{array}$ & $\begin{array}{c}\text { Ulecr index (mm) } \\
\text { mean -s.e. }\end{array}$ \\
1 & Donryu & 40 & 43.7 .3 .4 \\
2 & Sprague-Dawley & 40 & $22.7+2.9$ \\
3 & Wistar & 40 & 15.42 .4 \\
& P & & $1: 2.0 .001$ \\
& & & $1: 3.001$ \\
& & & $2: 3-0.001$ \\
\hline
\end{tabular}

Aspirin at $100 \mathrm{mg} / \mathrm{kg}$ was given orally $10 \mathrm{~min}$ after pylorus ligation. The animals were sacrificed $7 \mathrm{hr}$ after pylorus ligation. 


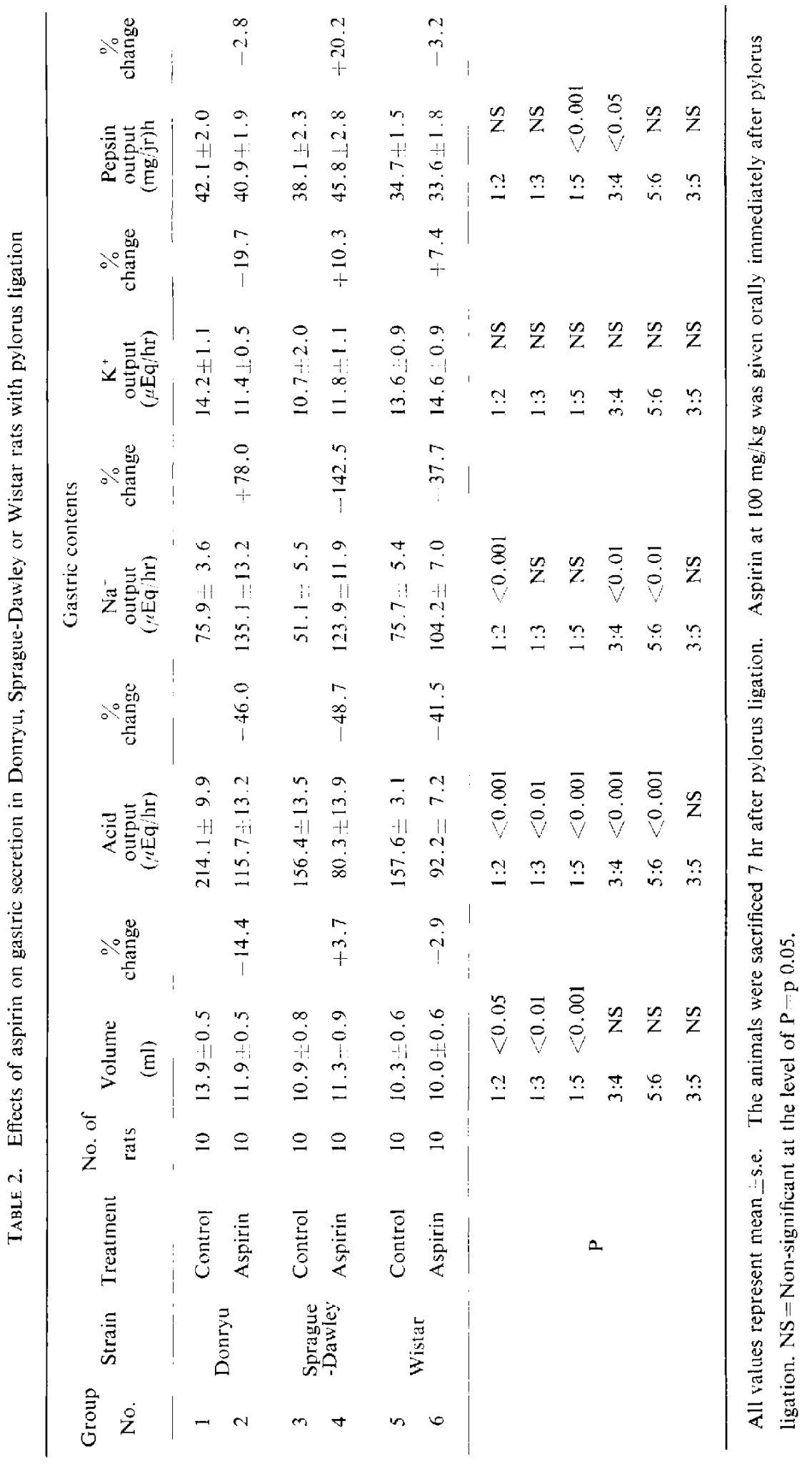




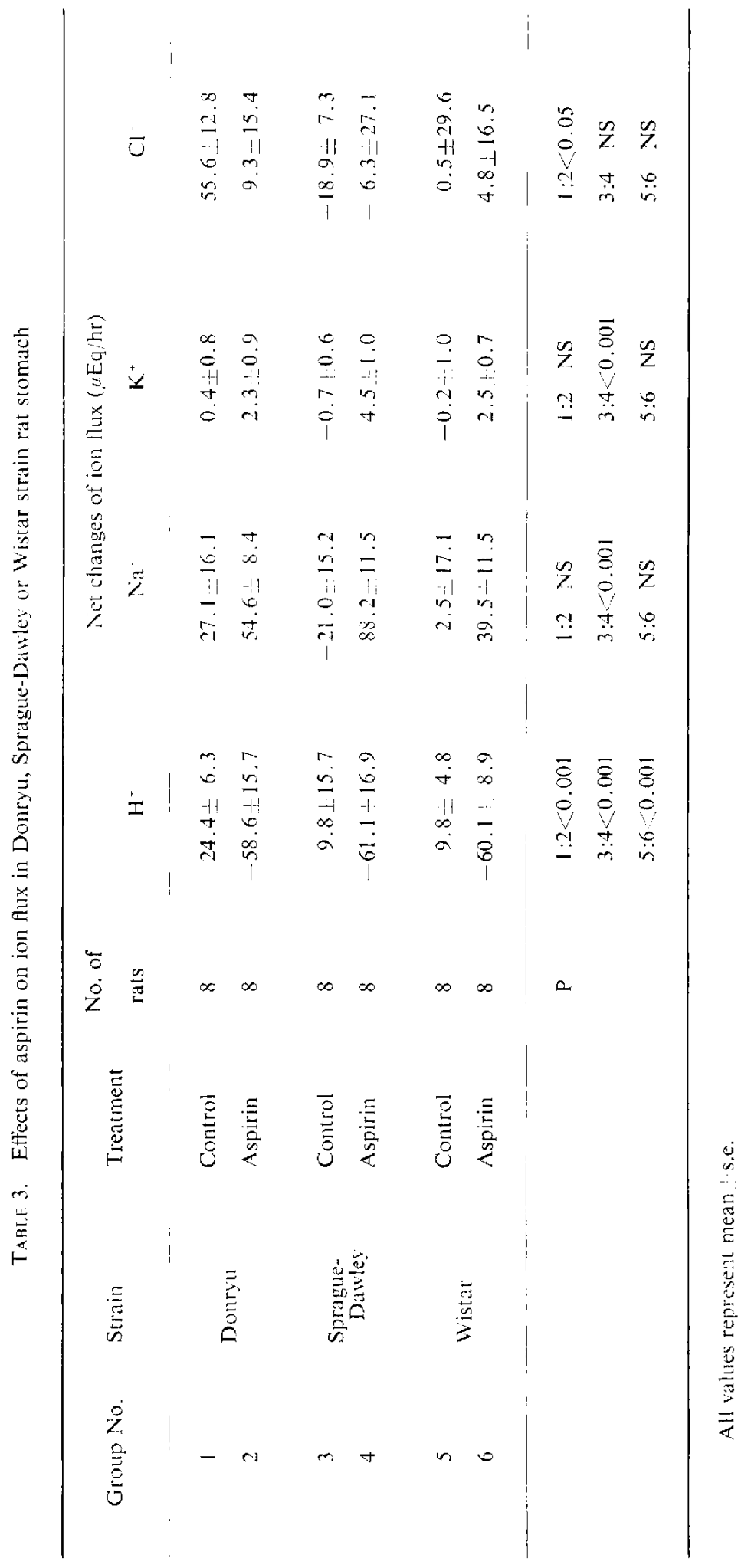


TABle 4. Serum aspirin esterasc activity in Donryu, Sprague-Dawley or Wistar strain rats

\begin{tabular}{clcc}
\hline Group No. & Strain & $\begin{array}{c}\text { No. of } \\
\text { rats }\end{array}$ & $\begin{array}{c}\text { Aspirin esterase activity } \\
\text { salicylic acid/serum ml/hr) } \\
\text { mean } / \text { s.e. }\end{array}$ \\
1 & Donryu & 10 & $178+10$ \\
2 & Sprague-Dawicy & 10 & $136 ! 5$ \\
3 & Wistar & 10 & $140 ! 9$ \\
& - & $\mathrm{P}$ & $1: 2<0.001$ \\
& & $1: 3<0.05$ \\
& & $2: 3$ N.S. \\
\hline
\end{tabular}

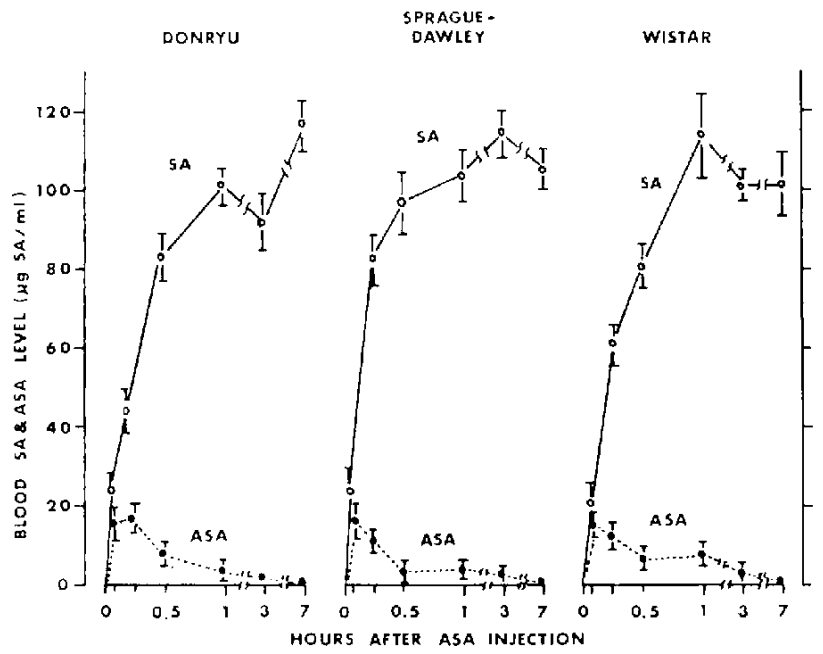

Fici. 1. Blood level of aspirin (ASA) and salicylic acid (SA) in Donryu, SpragucDawlcy or Wistar strain rats given $100 \mathrm{mg} / \mathrm{kg}$ of aspirin orally immediately after pylorus ligation. Each group included six rats of each strain.

\section{Aspirin and salicylic acid in blood}

Aspirin in the blood reached a peak value within 10 to 15 min after oral adninistration, after which the concentration rapidly decreased (Fig. 1). Changes in aspirin concentration were almost the same among the three strains. The level of salicylic acid reached a plateau within 30 to $60 \mathrm{~min}$, and this level was maintained for $7 \mathrm{hr}$.

\section{Prothrombin time}

Prothrombin time in rats treated with $1 \% \mathrm{CMC}$ solution alone was not significantly different among the thee strains (Table 5). Aspirin significantly prolonged the prothrombin time in Sprague-Dawley rats only.

\section{Hexosamine content}

As can be seen in Table 6, the hexosamine content in gastric juice from Donryu, SpragueDawley and Wistar rats given $1 \%$ CMC solution alone did not significantly differ among the strains. Wistar rats, however, showed a significantly higher content of hexosamine 
Table 5. Effect of aspirin on the prothrombin time in Donryu, Sprague-Dawley or Wistar rats

\begin{tabular}{llcc}
\hline Strain & Treatment & $\begin{array}{c}\text { No. of } \\
\text { rats }\end{array}$ & $\begin{array}{c}\text { Prothrombin time } \\
\text { mean } \pm \text { s.e. }\end{array}$ \\
Donryu & Control & 6 & $\cdots$ \\
& Aspirin & 6 & $38.4 \pm 1.0$ \\
Sprague-Dawley & Control & 6 & $45.6 \pm 3.2$ \\
& Aspirin & 6 & $39.8 \pm 1.0$ \\
Wistar & Control & 6 & $62.4 \pm 6.5^{*}$ \\
& Aspirin & 6 & $42.8 \pm 1.8$ \\
\hline
\end{tabular}

Aspirin at $100 \mathrm{mg} / \mathrm{kg}$ was given orally immediately after pylorus ligation. Prothrombin time was measured $7 \mathrm{hr}$ after pylorus ligation. $\quad * \mathrm{P}<0.05$.

Table 6. Hexosamine content in gastric mucosa or gastric juice in Donryu, SpragucDawley or Wistar strain rats

\begin{tabular}{|c|c|c|c|c|c|}
\hline Group No. & Strain & $\begin{array}{l}\text { No, of } \\
\text { rats }\end{array}$ & & \multicolumn{2}{|c|}{$\begin{array}{c}\text { Hexosamine content in the stomach } \\
\text { ("tg g mucosa or } / \mathrm{g} / \mathrm{g} \text { julice) } \\
\text { mean s.e. }\end{array}$} \\
\hline 1 & \multirow{3}{*}{ Donryu } & 6 & Mucosa & Control & $1549 \div 15$ \\
\hline 2 & & 6 & & Aspirin & $1313 \pm 37$ \\
\hline 3 & & 6 & Juice & Control & $4104 \div 294$ \\
\hline 4 & \multirow{5}{*}{ Sprague-Dawley } & 6 & & Aspirin & $4641 \pm 294$ \\
\hline 5 & & 4 & Mucosa & Control & $1527-58$ \\
\hline 6 & & 4 & & Aspirin & $1461 \pm 67$ \\
\hline 7 & & 5 & Juice & Control & $3644 \pm 141$ \\
\hline \multirow[t]{8}{*}{8} & & 5 & & Aspirin & $6032 \div 397$ \\
\hline & \multirow{4}{*}{ Wistar } & 5 & Mucosa & Control & $1771+62$ \\
\hline & & 5 & & Aspirin & $1388 \pm 67$ \\
\hline & & 4 & Juice & Control & $3786 \pm 413$ \\
\hline & & 4 & & Aspirin & $5016 \pm 387$ \\
\hline & \multirow[t]{3}{*}{$\mathbf{P}$} & & $1: 2<0.001$ & $3: 4$ NS & $5: 6 \quad \mathrm{NS}$ \\
\hline & & & $7: 8<0.001$ & $9: 10<0.05$ & $11: 12 \quad$ NS \\
\hline & & & $1: 5 \quad \mathrm{NS}$ & $1: 9<0.01$ & $5: 9<0.05$ \\
\hline
\end{tabular}

in gastric mucosa as compared with other strains. Hexosamine contents in gastric mucosa in the three strains tended to decrease with aspirin ingestion, while increase in the content in the gastric juice was noted.

\section{DISCUSSION}

The present studies indicate that there is a strain difference in susceptibility to aspirin ulceration in rats. The stomach of Donryu strain rats was found to be the most sensitive to aspirin, compared to Sprague-Dawley and Wistar strains. Sprague-Dawley rats were significantly more sensitive to the agent than Wistar rats. Various experiments were carried out to elucidate the contributing factors for these differences from physiological and pharmacological points of view.

It is widely accepted that a ccrtain amount of gastric acid is a necessary factor for the 
development of aspirin ulcers $(15,16)$. Thus, it was postulated that Donryu rats might secrete a much greater quantily of acid than Sprague-Dawley or Wistar rats. In fact, gastric analysis demonstrated that Donryu rats showed a significantly higher gastric acid output than Sprague-Dawley or Wistar rats. Therefore, there is the possibility that excessive acid might contribute to the high incidence of aspirin ulcers in Donryu rats. However, there was no difference in acid output between Sprague-Dawley and Wistar rats despite differences in ulcer indices of these groups.

It has been proposed that aspirin induces gastric ulcers by disrupting the gastric mucosal barrier resulting in the back diffusion of acid (17). The administration of aspirin produced a significant decrease of gastric acid output in the gastric juice, almost to the same degree in the three strains, and increment of $\mathrm{Na}^{+}$ion output in different degrees. These findings were also confirmed in the experiment done in the denervated rat stomach; ionic changes in response to aspirin were almost equal in Donryu, Sprague-Dawley or Wistar rats. These data indicate that the gastric mucosal barrier is much the same among the three strains.

Menguy et al. $(10,18)$ reported that aspirin esterase activity in human blood was lower in females and cirrhotic patients than in healthy males. Females and cirrhotic patients are known to be much more sensitive to aspirin induced bleeding or ulceration $(19,20)$. Therefore, they suggested that the low activity of aspirin esterase might contribute to the ulcerogenicity of the drug. Our present investigations showed that Donryu rats had a significantly higher activity of aspirin esterase than Sprague-Dawley or Wistar rats. Moreover, the degree of absorption and fate of aspirin from the rat stomach was almost identical among these three strains. Thus, these data show that aspirin esterase did not play an important role in the strain difference observed in aspirin ulcers in rats.

It was reported that chronically injected aspirin tends to prolong platelet aggregation (21). Our results showed that the prothrombin time of each strain of rats was almost equal. Only Sprague-Dawley rats indicated a prolongation of prothrombin time in response to aspirin.

Finally, hexosamine is one of the mucus components considered to play an important role in the maintenance of integrity of gastric mucosa (22). We observed that the hexosamine content in gastric mucosa of Donryu rats was significantly lower than that in Wistar rats, but such was not the case in the gastric juice. Here the difference was large, and such may not have contributed to the marked resistance of gastric mucosa of Wistar rats to aspirin. The administration of aspirin resulted in a reduction of hexosamine in the gastric mucosa and increase of the amine in the gastric juice, almost to the same degree in all three strains of rats.

It appears that the Donryu strain is the best of the three used herein for determining the high incidence of aspirin ulceration, for the study of ulcerogenicity of aspirin, and for the assay of possible antiulcer agents for aspirin studies.

Acknowledgement: Thanks are due to Professor Carl J. Pfeiffer for reading the manuscript. 


\section{REFERENCES}

1) Pffiffer, C.J. and Lewandowski, L.G.: Comparison of gastric toxicity of acetylsalicylic acid with route of administration in the rat. Archs int. Pharmacodyn. Thér. 190, 5-13 (1971)

2) BRodie, D.A. AND HoOK1, K.F.: Effects of route of administration on the production of gastric hemorrhage in the rat by aspirin and sodium salicylatc. Am. J. dig. Dis. 16, 985-989 (1971)

3) Guth, P.H., Paulsen, G., Iynd, D. and Aures, D.: Mechanism of prevention of aspirininduced gastric lesions by bile duct ligation in the rat. Gastroenterology 71, 750-753 (1976)

4) Kriegel, V.H. AND Scuramm, E. : Zur Frage der Auslosung von Gastrointestinalen Blutungen durch Acetylsalicylicsaure und Acetylsalicy/saure enthaltende Medikamente bei der Ratte. Arzheim.-Forsch. 24, 1590-1593 (1974)

5) Yeomans, N.D.: Electron microscopic study of the repair of aspirin-induced gastric crosions. Am. J. dig. Dis. 21. 533-541 (1976)

6) Okabe, S., Takeuchi, K., Nakamura, K. and Takagi, K.: Pathogenesis of gastric lesions induced by aspirin in the pylorus-ligated rat. Japan. J. Pharmacol. 24, 363-371 (1974)

7) Okabe, S., Honda, K., TAKeuchi, K. and Takagi, K.: Inhibitory effect of L-glutamine on gastric irritation and back diffusion of gastric acid in response to aspirin in the rat. Am. J. dig. Dis, 20, 626-631 (1975)

8) ANSON, M.L.: The estimation of nepsin, trypsin, papain and cathepsin with hemoglobin. J. gen. Physiol. 22, 79.89 (1938)

9) Hlint, J.N. And Knox, M.T.: The regulation of gastric emptying of meals containing fibric acid and salts of citric acid. $J$. Physiol. 163, 34-45 (1962)

10) Mengly, R., Desbaillets, L., Okare, S. a.io Masters, Y.F.: Abnormal aspirin metabolism in patients with cirrhosis and its possible relationship to bleeding in cirrhotics. Ann. Surg. 176, 412-418(1972)

11) Leonard, J.R.: Presence of acetylsalicylic acid in plasma following oral ingestion of aspirin. Proc. Soc. exp. Biol. Mcd. 110, 304,308 (1962)

12) COTTY, V.F. AND EDFrma, H.M.: Method for direct measurement of acetylsalicylic acid in human blood. J. Pharm. Sci, 55, 837-839 (1966)

13) Campefli, H.A., SMith, W.K., Rogerts, W.L. AND Link, K.P.: Studies on the hemorrhagic sweet clover disease. (2) The bioassay of hemorrhagic concentrates by following the prothrombin level in the plasma of rabbit blood. I. biol. Chem. 138, 1-20 (1941)

14) Masamune, H. and Yoshizawa, Z.: Biochemical study on carbohydrates. An improvement of the fractionated detcrmination method by paper partition chromatography of glucosamine and galactosamine. Tohoku J. exp. Med. 65, 169-176 (1957)

15) Gottschalk, $A$. and Menguy, R.: Role of gastric acid in aspirin-induced erosive gastritis. Proc. Soc. exp. Biol. Med. 135, 384-388 (1970)

16) CoOKe, A.R.: The role of acid in the pathogenesis of aspirin-induced gastrointestinal erosions and hemorrhage. Am. J. dig. Dis. 18, 225237 (1973)

17) Davenport, H.: Salicylic damage to the gastric mucosal barricr. New Engl. I. Med. 276, $1307-1312(1967)$

18) Menguy, R., Desbaillets, L., Masters, Y.F. and Orabe, S.: Evidenee for a sex-linked difference in aspirin metabolisin. Nature 239, 102-103 ([972)

19) Billington, B.P.: The Austratian gastric ulcer change: interstate variations. Aust. Anm. Med. $12,153-162(1963)$

20) Spro, H.M.: Clinical Gastruenterology. p. 238, MacMillan, London (197())

21) Quick, A.J. AND Cuscriki, L.: luffuence of acelylsalicylic acid and salicylanide on the coagulation of blood. J. Phamacol. exp. The' 128, 95-98 (1960)

22) Minguy, R. and Disiallelits, L.: Gastric mucous barrier; influence of protein-bound carbohydrate in mucus on rate of protcolysis of gastric mucus. Aml. Surg. 168, 475-482 (1968) 